\title{
Uranium in Western Europe
}

by

J. Dardel

Although the element uranium was only named in 1789 (by Klaproth) and was first isolated in metallic form in 1841 (by Péligot), it has been used in Europe since the Middle Ages. Miners in Saxony who worked silver in the Middle Ages had identified pitchblende, or uranium oxide, while potters concocted from it a pigment which gave a glistening greenishyellow tint to glass and pottery.

Yet it was not until 1904 that the working of uraniferous minerals on an industrial scale began in Portugal and Czechoslovakia for the production of radium. In Europe, mining began again soon after World War II for the production of uranium as a fissile material.

\section{Resources and Production}

Western Europe's uranium resources ${ }^{1}$ represent about a tenth of world resources, or 486950 tonnes of uranium (tU) recoverable at a cost of less than $\$ 130$ per kilogram of uranium. These resources were of the same order of magnitude in 1978 as the cumulative world production (532 $700 \mathrm{tU}$ ) during that year.

Production in Western Europe in 1978 was 2,513 tU. In 1978 and 1979, the Federal Republic of Germany, Spain, France and Portugal were amongst the producing countries and at the end of 1978, their combined resources were $142150 \mathrm{tU}$.

\footnotetext{
${ }^{1}$ That is, those of F.R.G., Spain, Finland, France, Italy, Portugal, United Kingdom, Sweden, Switzerland and Yugoslavia.
}

EPISODES, Vol. 1980, No. 1 
Nevertheless, production for the whole of Europe in 1978 may have amounted to about 10000 tU (U.S.S.R., France, Czechoslovakia, Hungary, Romania and the German Democratic Republic being the main producing countries). This may have represented about a quarter of world production (exclusive of China).

\section{Main Deposits}

The world's main uranium-bearing provinces occur in Precambrian shields (South Africa, Australia, Canada) or in the sedimentary cover of Precambrian shields (U.S.A., Niger). In Europe, though large quantities of uranium are known to exist in the Cambrian black shales of the Baltic Shield, vein deposits are more particularly associated with the Moldanubian granites of the Variscan orogeny, while deposits in the enclosing sedimentary cover are in the Permian-toPalaeogene detritus derived from erosion of the Variscan chain.

Europe's present production and reserves of uranium are for the most part in vein deposits associated with granitoids, deposits in sediments (grits, lutites and carbonaceous shales), and those related to volcanic rocks in vulcano-sedimentary sequences.

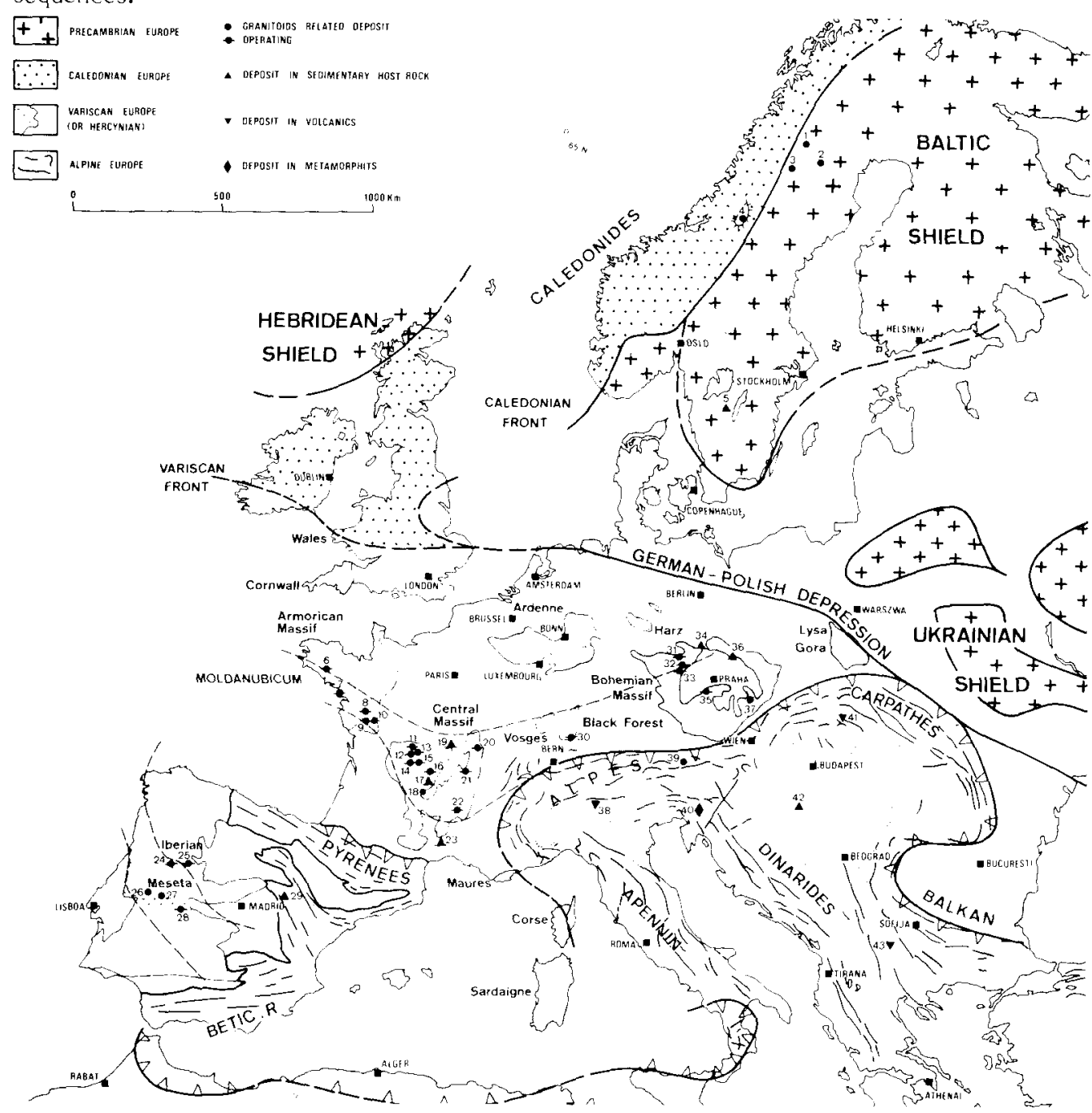

Figure 1. Main uranif erous deposits in Europe: Sweden: 1. Pleutajokk 2. Ravaberget 3. Dubblon 4. Hotagen 5. Ranstad; France: 6. Pontivy 7. Pennaran 8. Ecarpière-Le Chardon 9. Beaurepaire 10. La Chapelle Largeau - La Commanderie - La Dorgissiere 11. Le Bernardan 12. Le Brugeaud 13. Bellezane 14. Margnac-Peny 15. Fanay - Le Fraisse 16. Hyverneresse 17. St-Pierre du Cantal 18. Bertholène 19. Cerilly 20. Grury 21. Bois Noirs 22. Le Cellier - Les Pierres Plantées 23. Mas Laveyre; Portugal: 24. Urgeirica; Spain: 25. Fe; Portugal: 26. Nisa 27. Tarabau; Spain: 28. El Pedrigal 29. Mazarete; F.R.G.: 30. Menzenschwand; G.D.R.: 31. Aue; Czechoslovakia: 32. Jachymov district 33. Horni Slavkov; G.D.R.: 34. Koenigstein; Czechoslovakia: 35. Pribram district 36. Hamr 37. Rozna-Olsi; Italy: 38. Novazza; Austria: 39. Forstau; Yugoslavia: 40. Zirovski Vrh; Czechoslovakia: 41. Huta-Muran; Hungary: 42. Mecsek; Yugoslavia: 43. Zletovska Reka.

EPISODES, Vol. 1980, No. 1
At present, vein deposits worked in the Variscan province of Europe are associated spatially with granitoids being either metamorphic rocks in the aureoles around granite plutons Intragranitic vein deposits occur in the Iberian Meseta (Urgeiriça and Borrega in Portugal), in the Armorican massif and the Massif Central (La Commanderie, l'Escarpière; le Black Forest (Menzenschwand).

The Fanay and Margnac deposits in the western Massif Fure in a muscovite-biotite leucogranite. The minerCones vary in form from a linear type with vein contan to a columnar type. "Linear" mineralizations are of phylites. They occur either as a single vein-infilling or in "threads" of stockworks. Columnar mineralizations im"pipes" of vacuolar rock formed by dissolution of quartz by solutions from the enclosing leucogranite. These are locally called episyenites.

Primary uranium mineralization is mainly pitchblende, accompanied in many cases by coffinite and/or black oxides with scattered iron sulphides.

Perigranitic vein deposits occur in the Iberian Meseta (Fé and El Perdrigal in Spain, Nisa in Portugal), in the Massif Central (Les Bondons, France) and in the Bohemian Massif (Pribram and Jachymov in Czechoslovakia, and Aue in G.D.R.). They have the following in common:

- mineralization is in Proterozoic to Palaeozoic rocks close to the contact with a leucogranite of Variscan age (maximum distance from the contact is $1 \mathrm{~km}$ in the Iberian Meseta and $2 \mathrm{~km}$ in the Bohemian Massif);

- presence of pyritous and carbonaceous schists and lenses in the metasedimentary sequence in which the deposits occur is characteristic;

- mineralization appears to have impregnated zones of cataclasis or crushing at the intersection of old clay-filled fault fissures or of certain facies rich in pyrite and carbonaceous material (Pribram) or in amphibolites (Jachymov).

The nature of the metasediments, their degree of alteration and the geochemistry of the mineralization vary from one district to another. The uranium itself is either in the form of secondary minerals in the schists of EI Perdrigal and $\mathrm{Fe}$ (within a depth of $50 \mathrm{~m}$ ), or in the form of pitchblende in the gneisses, amphibolites and micaschists of Jachymov and Aue, accompanied by minerals containing $\mathrm{Bi}, \mathrm{Co}, \mathrm{Ni}$ and $\mathrm{Ag}$, or in the shales and slates of Pribram, where ores of $\mathrm{Pb}, \mathrm{Zn}, \mathrm{Ag}$ and $A u$ are also worked nearby. 


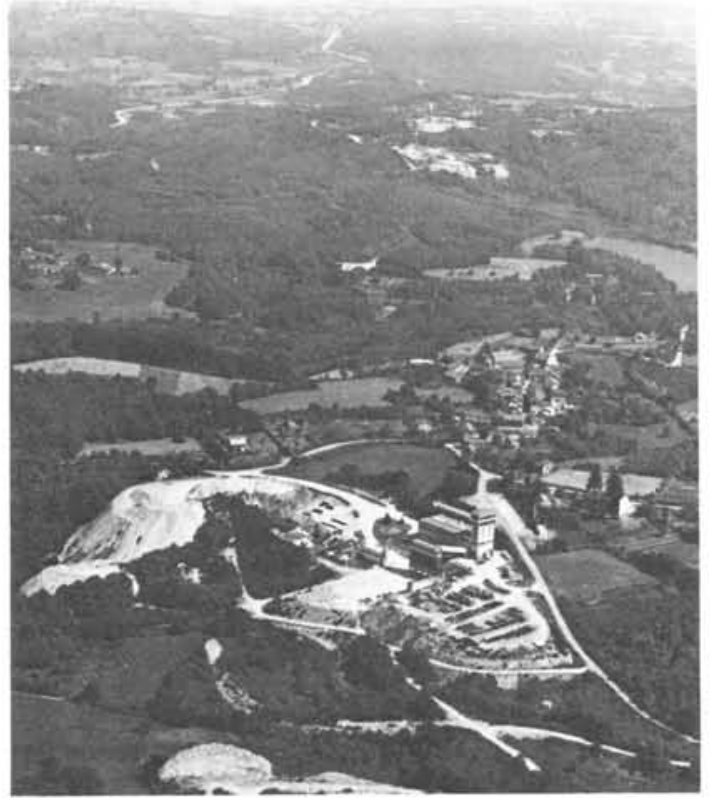

The Fanay and Fraisse mines (Haute-Vienne) in northern Limousin (France). The Fanay mine has $50 \mathrm{~km}$ of workings to a depth of $300 \mathrm{~m}$. (Photo courtesy Commissariat à l'Energie Atomique, France)

\section{Sedimentary Deposits}

Deposits associated with sedimentary rocks occur in the Cambrian carbonaceous shales of Ranstad in southern Sweden, in the Permian lutites and silts of Lodève (France) and in Permian to Palaeogene grits elsewhere in Europe. At Ranstad, the uranium is stratiform ( 2.5 to $4 \mathrm{~m}$ thick) in an Upper Cambrian bituminous shale horizon. The ore is of low metal content (average $0.03 \% \mathrm{U}$ ), with $22 \%$ carbonaceous material and $13 \%$ pyrite, but the volume of the ore is very large (300 $000 \mathrm{tU})$.

At Mas Laveyre in the Permian basin of Lodève, the mineralized sequence is characterized by fine-grained rhythmic sediments of marsh to lagoonal facies (arkosic carbonate silts, bituminous laminae, green argillites) or of floodplain facies (red clayey silts). Mineralization occurs in layers or in masses in fault zones; uranium is present in pitchblende or coffinite, or in association with carbonaceous material.

Other deposits occur in sandstones of (i) Permian age - at Lombre (France), Mecsek (Hungary), and Zirovski Vrh (Yugoslavia); (ii) Triassic age - at Mazareta (Spain); (iii) Cretaceous age - at Hamr (Czechoslovakia) and Koenigstein (G.D.R.); and (iv) Palaeogene age - at St. Pierre du Cantal (France).

At Lombre, mineralization occurs in former meandering river channels, especially at the transition between downcutting sandstones and carbonaceous silts. The uranium is in pitchblende and coffinite accompanied by pyrite, marcasite and carbonaceous material. At St. Pierre du Cantal, mineralization is in Oligocene arkosic sands channelling into the lutites of a former floodplain, and is commonly restricted to zones rich in carbonaceous material at the base or top of sand bodies. The uranium, which occurs mainly as a secondary mineral, is accompanied by minerals containing V, P, Se and As.

\section{Volcanic Deposits}

Deposits associated with vulcanites are present in Alpine areas, in particular at Novazza in the Bergamo Alps (Italy), at Huta-Muran in the Carpathians (Hungary), and at Zletovska Reka between the Dinarides and the Macedonian massif (Yugoslavia). At Novazza, mineralization is in an acid ignimbrite of a Permian sedimentary volcanic formation. Pitchblende is accompanied by zinc, lead and molybdenum mineralization. At Novoveska Huta-Muran in the Spis-Gemer EPISODES, Vol. 1980, No. 1 massif, mineralization occurs in tuffs, lutites and sandstones within a Permian sedimentary volcanic formation. Pitchblende is associated with copper and molybdenum minerals. Mineralization at Zletovska Reka is in Cenozoic dacitic and andesitic vulcanics in which the uranium occurs as black oxides associated with pyrite.

Operational mines at present are mainly in the Variscan province and in particular in the Moldanubian zone. Recent exploration has also revealed deposits of possible economic potential in the Precambrian province. For example, the Arvidsjaur and Arjeplog occurrences in northern Sweden have striking analogies with the Precambrian deposits of Beaverlodge, Canada.

Europe's move toward independence in energy necessitates an increase in production of uranium from the region's resources, and hence, vigorous exploration to locate the undiscovered reserves. In fact, it is only if the current rate of exploration is maintained through the eighties that the rate of production will keep pace with European demand predicted for the year 2000.

\section{References}

Anonymous, 1979, Uranium - Ressources, Production et Demande: NEA-OECD/IAEA, (in press).

Ruzicka, V., 1971, Geological comparison between east European and Canadian uranium deposits: Geol. Surv. Canada, Paper 70-48, 196 p.

Ziegler, V., 1974, Essais de Classification Metallotectonique des Gisements d'Uranium, in Formation of Uranium Ore Deposits: IAEA, Vienna, No. STI/Pub/374, p. 661-677.

\section{ABOUT THE AUTHOR:}

Jacques Dardel has been with the uranium exploration division of the French Commissariat à l'Energie Atomique (Atomic Energy Commission) since 1954, and has served on assignments in Madagascar, Turkey, Africa and Canada. In charge of the exploration and development of Cluff Lake mine in Saskatchewan, Canada from 1967 to 1975, he was with the Fanay mine in Haute Vienney, France from 1975 to 1978.

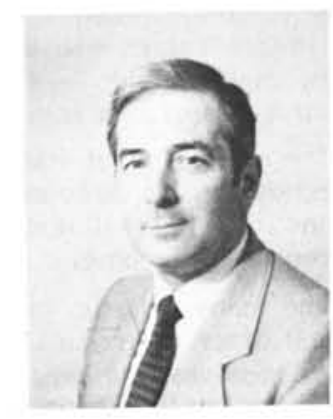

EDITOR'S NOTE: Some of the preceding articles were originally submitted in French. The task of translating them into English was undertaken by Richard V. Melville, to whom EPISODES owes a special vote of thanks. A palaeontologist, Dr. Melville is currently Secretary of the International Commission on Zoological Nomenclature. He retired as an Assistant Director of the Institute of Geological Sciences (U.K.) in 1974. From 1961 to 1965, Dr. Melville served as Scientific Counsellor at the British Embassy in Paris. (Copies of the original French texts are available, on request, from the IUGS Secretariat, Room 177, 601 Booth Street, Ottawa, Canada K1A 0E8.)

A word of thanks also to Dr. Henri J. Radier, exploration manager at Elf Aquitaine in France, who helped to assemble the articles on energy in the last series of sketches.
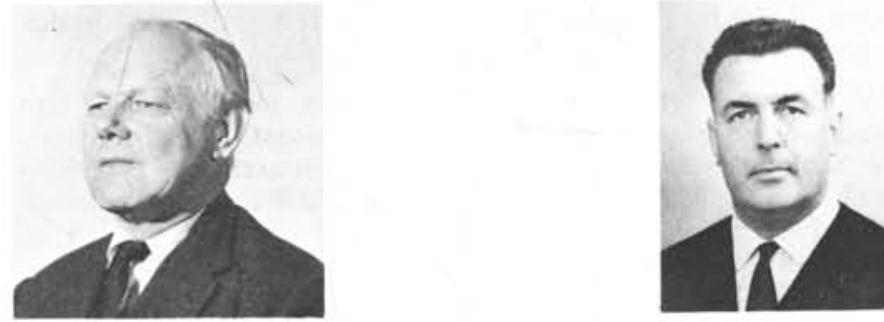

Richard Melville 